\title{
Honey Combination Therapies for Skin and Wound Infections: A Systematic Review of the Literature
}

This article was published in the following Dove Press journal: Clinical, Cosmetic and Investigational Dermatology

\author{
Pauline McLoone' \\ Dina Tabys' \\ Lorna Fyfe $\mathbb{D}^{2}$
}

'Department of Biomedical Sciences, Nazarbayev University School of Medicine, Nur-Sultan 010000,

Kazakhstan; ${ }^{2}$ Dietetics, Nutrition, and Biological Sciences, Queen Margaret University, Musselburgh, East Lothian EH2I 6UU, UK
Correspondence: Pauline McLoone Department of Biomedical Sciences, Nazarbayev University School of

Medicine, Nur-Sultan 010000, Kazakhstan

Tel +7-775-365-14-72

Email pauline.mcloone@nu.edu.kz

\begin{abstract}
Topical application of medical grade honey is recommended for the clinical management of wound infections. The suitability of honey as a wound healing agent is largely due to its antibacterial activity, immune modulatory properties, and biocompatibility. Despite the usefulness of honey in wound healing, chronic wound infections continue to be a global problem requiring new and improved therapeutic interventions. Several recent studies have investigated the effects of combining honey with other therapies or agents with the aim of finding more efficacious treatments. In this systematic review, the database PubMed was used to carry out a search of the scientific literature on the combined effects of honey and other therapies on antimicrobial activity and wound and skin healing. The search revealed that synergistic or additive antimicrobial effects were observed in vitro when honey was combined with antibiotics, bacteriophages, antimicrobial peptides, natural agents, eg, ginger or propolis and other treatment approaches such as the use of chitosan hydrogel. Outcomes depended on the type of honey, the combining agent or treatment and the microbial species or strain. Improved wound healing was also observed in vivo in mice when honey was combined with laser therapy or bacteriophage therapy. More clinical studies in humans are required to fully understand the effectiveness of honey combination therapies for the treatment of skin and wound infections.
\end{abstract}

Keywords: honey, antibiotics, natural agents, combination therapy, wound infection, skin infection

\section{Introduction}

Antimicrobial drug resistance is a major public health problem for which novel antimicrobial drugs or innovative therapeutic interventions must urgently be found. Globally, incalcitrant wounds, caused by antibiotic-resistant microbial infections, are a significant burden on health-care systems. ${ }^{1,2}$ An increasing global prevalence of diabetes and obesity and an aging population has contributed to the current burden of chronic wounds. ${ }^{3,4}$ Non-healing-infected wounds can cause sepsis and inflammation in organs, eg, endocarditis leading to increased morbidity and mortality. Wounds with biofilms are particularly resistant to treatment with antibiotics because the bacteria are protected by a barrier of extracellular polymeric substances. ${ }^{5}$ Due to the need for new and improved therapies, there has been a revived interest in alternative treatment approaches such as the use of honey in the management of wound infections. Indeed, medical grade honey is currently included in clinical protocols for wound management ${ }^{6,7}$ and has been shown to have broad spectrum antimicrobial activity 
against common wound infecting microorganisms including Staphylococcus aureus, Pseudomonas aeruginosa and Escherichia coli. ${ }^{8-10}$ Furthermore, honey can kill antibioticresistant bacterial strains such as methicillin-resistant Staphylococcus aureus (MRSA) and the development of bacterial resistance to honey is thought to be unlikely due to its multiple antimicrobial components and mechanisms. ${ }^{11}$ The wound healing ability of honey is also related to its capacity to promote reepithelialisation and angiogenesis and stimulate skin and immune cells. ${ }^{12-15}$ Medical grade honey is defined as organic honey that is free of toxic contaminants, has been sterilised by gamma irradiation, is processed in accordance with safety regulations and standards and is safe for medical application. ${ }^{16}$ Medical grade honey formulations for the clinical management of wounds include honey in tubes, gels, and impregnated dressings. A Cochrane systematic review published in 2015 concluded that there is evidence that honey heals partial thickness burn wounds better than conventional treatments and post-operative wounds more effectively than gauze or antiseptics. ${ }^{17}$ For other types of wounds, the review stated that there was insufficient evidence to form definitive conclusions. Therefore, despite evidence that honey is efficacious for the treatment of certain types of wounds, there is still a need to find ways to optimise or enhance its antimicrobial and healing properties for improved clinical outcomes. As all honeys are unique, one approach may be to search for honeys that have superior antimicrobial activity but are yet undiscovered. Another approach may be to modify the honey in such a way that its antimicrobial activity is boosted. Surgihoney is an example of a honey that has been bioengineered so that it produces more hydrogen peroxide and reactive oxygen species when diluted in water. ${ }^{18}$ An alternative approach could involve combining honey with other agents such as antibiotics or natural agents such as ginger or propolis with the aim of inducing synergistic or additive effects. This systematic review explores the current scientific literature on the biological and clinical effects of combining honey with other agents and therapies in relation to wound and skin infections. Furthermore, possible mechanisms of the synergistic effects of honey combination therapies are described. The overall aim of this article was to encourage the development of new and improved treatments for skin and wound infections.

\section{Review Methods}

A systematic review investigating the effects of honey combined with other agents or therapies on antimicrobial activity and wound and skin infections was conducted in
Table I Search Terms Used in the Study

\begin{tabular}{|l|l|l|}
\hline Term (Group I) & Term (Group 2) & Term (Group 3) \\
\hline Honey & Antibiotic & Wound infection \\
& Rifampicin & Skin infection \\
& Oxacillin & Wound healing \\
& Tetracycline & Antibacterial \\
& Combination therapy & Antimicrobial \\
& Propolis & \\
& Herbal extracts & \\
\hline
\end{tabular}

Note: Combinations: group I terms AND group 2 terms AND group 3 terms until all combinations had been searched for.

accordance with PRISMA guidelines. ${ }^{19}$ The electronic database PubMed was used for the literature search by using key terms shown in Table 1. Group 1 terms were combined with group 2 and 3 terms until all the combinations had been searched for. Research articles investigating the combined effects of honey and other agents or therapies on antibacterial activity in vitro and on wound and skin infections in vivo were included in the study. Other agents included antibiotics commonly used for skin and wound infections such as rifampicin, oxacillin and tetracycline and other natural products such as propolis, royal jelly, vitamins, and ginger. Examples of other therapies included laser therapy, bacteriophage therapy and hydrogel. Articles with full text in English and published between 1990 and 2020 were included in the study. Review articles and articles not written in English were excluded. Some important articles were also sourced from the reference list of included papers and some were recommended by experts in the field. PM and DT carried out the literature search including selection and assessment of articles and the search was conducted between May and June 2020. Any disagreements during the article assessment process were resolved by discussion. We obtained a total of 408 scientific articles and selected 41 studies we determined relevant to research on honey combination therapies for wound and skin infections (Table 2).

\section{Results and Discussion}

\section{Honey and Antibiotics: In vitro Studies}

Several researchers have explored the effects of combining honey with antibiotics on antimicrobial activity in vitro. One of the first papers reporting a synergistic effect of honey and antibiotics was published in 1998. The researchers used a broth dilution assay to demonstrate a synergistic effect of an Indian honey (obtained from Phondaghat Pharmacy) and the antibiotics amikacin, 
Table 2 Table Created in Accordance with PRISMA Guidelines Showing Number of Articles Identified and Included in This Systematic Review

\begin{tabular}{|l|l|l|}
\hline $\begin{array}{l}\text { Search } \\
\text { Strategy }\end{array}$ & & $\begin{array}{l}\text { No. of } \\
\text { Articles }\end{array}$ \\
\hline Identification & $\begin{array}{l}\text { Records identified from PubMed } \\
\text { database searching } \\
\text { Records identified from other sources }\end{array}$ & 397 \\
\hline Screening & $\begin{array}{l}\text { Records after duplicated articles } \\
\text { removed } \\
\text { Records screened by abstract } \\
\text { Records excluded }\end{array}$ & 254 \\
\hline Eligibility & $\begin{array}{l}\text { Full text articles assessed for eligibility } \\
\text { Full text articles excluded }\end{array}$ & 47 \\
\hline Included & Studies included in review & 41 \\
\hline
\end{tabular}

Note: ${ }^{\top}$ Other sources included articles sourced from the reference list of selected papers and articles recommended by experts in the field.

ceftazidime and gentamicin against multidrug-resistant clinical isolates of $P$. aeruginosa. ${ }^{20}$ The honey and antibiotics were reportedly tested at a ratio of $1: 1$. Experiments were also conducted with Klebsiella species, but no synergy was observed with this micro-organism. Later in 2005, another study reported synergy using broth dilution method between an Omani honey (50\%) and the antibiotic gentamicin $(4 \mu \mathrm{g} / \mathrm{mL})$ against Staphylococcus aureus. $^{21}$ Additionally, a study conducted in Egypt reported enhanced effects of antibiotics against clinical isolates of $P$. aeruginosa, Enterobacter species and Staphylococci in a disc diffusion assay when citrus bee honey $(100 \%)$ was added to the antibiotic discs (Oxoid). ${ }^{22}$

More recently, Jenkins and Cooper (2012) ${ }^{23}$ investigated the combined effects of subinhibitory concentrations of manuka honey and the antibiotic oxacillin against methicillin-resistant Staphylococcus aureus (MRSA). In their study, resistance of the MRSA strain to oxacillin was confirmed by antibiotic susceptibility testing using Mueller Hinton Agar (MHA) and discs coated with $5 \mu \mathrm{g}$ of oxacillin. No zones of inhibition were observed confirming that the $S$. aureus strain was methicillin resistant. However, when a sub-inhibitory concentration of manuka honey $(5 \% \mathrm{w} / \mathrm{v})$ was added to the MHA, inhibition zones of $32 \mathrm{~mm}$ in diameter developed around the oxacillin discs. The findings suggest that the subinhibitory concentration of manuka honey affected the bacteria in such a way that resistance to oxacillin was reversed. Using broth dilution, chequerboards and time kill curves,
Jenkins and Cooper (2012) confirmed the synergistic interaction of manuka honey and oxacillin, and reversal of oxacillin resistance. $\beta$ lactam antibiotics such as oxacillin, methicillin and cefoxitin inhibit bacterial cell wall synthesis by binding to bacterial penicillin-binding protein (PBP), a protein involved in the synthesis of the peptidoglycan layer of the bacterial cell wall. In methicillinresistant strains of $S$. aureus, an altered PBP protein with a low binding affinity for $\beta$ lactam antibiotics is produced. This altered form of PBP is known as PBP-2a and is encoded by the mec $A$ gene and regulated by a sensor inducer called mecRl. Expression of mecA and subsequent production of PBP2a enables bacteria to survive in the presence of the $\beta$ lactam antibiotics. Jenkins and Cooper (2012) demonstrated using microarray technology that manuka honey $(10 \% \mathrm{w} / \mathrm{v})$ down regulated mecRl gene product in MRSA. However, synergistic effects of oxacillin and manuka honey have also been observed in methicillin-sensitive strains of $S$. aureus that do not have the $m e c A$ gene suggesting that other mechanisms are likely to be involved. ${ }^{24,25}$ Jenkins and Cooper (2012) ${ }^{26}$ went on to investigate antimicrobial activity of 15 antibiotics in combination with subinhibitory concentrations of manuka honey (Manukacare 18+, Comvita, 5\% w/v) against MRSA and P. aeruginosa. The results depended on the antibiotic, the bacterial species, and experimental method used. Most notable were the results of the combination of tetracycline and manuka honey which demonstrated enhanced activity against MRSA and $P$. aeruginosa. Rifampicin and manuka honey showed enhanced effects against MRSA when tested using disc diffusion and E-strip but synergy was not observed using broth dilution. The combination of imipenem and manuka honey was found to be synergistic against MRSA but not $P$. aeruginosa suggesting a species-specific effect. Subsequently, Müller et al $(2013)^{25}$ reported synergistic effects of manuka honey and rifampicin against several $S$. aureus isolates including MRSA. The experimental methods used were checkerboard, microdilution assays and agar disc diffusion assay. In the agar disc diffusion assay, for example, the addition of 5\% Medihoney (Comvita Ltd, NZ) to the agar increased the zone of inhibition induced by rifampicin $(4 \mu \mathrm{g}$ discs) from $20 \mathrm{~mm}$ to $41 \mathrm{~mm}$. A similar result was obtained for a range of $S$. aureus isolates; however, no zones of inhibition were observed around a rifampicin-resistant strain of S. aureus either with or without 5\% Medihoney in the agar suggesting that Medihoney could not reverse rifampicin resistance. Nevertheless, experimental results suggested 
that Medihoney could prevent the emergence of resistance as resistant colonies were observed on agar plates with rifampicin and 5\% sugar solution but not on rifampicin and 5\% Medihoney plates. Rifampicin is an effective drug for the treatment of $S$. aureus wound and skin infections, but resistance can emerge readily. Resistance is due to a single point mutation in the $r p o B$ gene that encodes the $\beta$ subunit of RNA polymerase, the target of rifampicin. The authors suggested that Medihoney could prevent occurrence of the mutations that cause resistance or Medihoney and rifampicin combination did not allow the bacteria to survive long enough to develop resistance. The researchers also investigated the effects of methylglyoxal (MGO), the main antimicrobial component of manuka honey, in combination with rifampicin on antibacterial activity and concluded that MGO $(70 \mu \mathrm{g} / \mathrm{mL})$ exerted an additive rather than a synergistic effect. The authors were of the view that MGO was not fully responsible for the synergistic antibacterial effects of manuka honey and suggested that other compounds in the honey such as polyphenols may be involved. Similarly, Hayes et al (2018) ${ }^{27}$ reported that manuka honey or MGO enhanced the activity of the antibiotic linezolid against both a methicillinsensitive and a methicillin-resistant strain of $S$. aureus. MHA plates that contained 5\% manuka honey (Manuka Health, Auckland, NZ) or MGO $(27.5 \mu \mathrm{g} / \mathrm{mL})$ compared to control plates containing a 5\% sugar solution caused a statistically significant increase in linezolid $(30 \mu \mathrm{g})$ induced zones of inhibition. In contrast, an unpasteurised honey did not enhance the activity of linezolid. Checkerboard microdilution assays determined that in this study, the effects of MGO were synergistic rather than additive. Linezolid is effective against many Grampositive bacteria including $S$. aureus and acts by inhibiting bacterial protein synthesis. The researchers went on to show that MGO increased the intracellular accumulation of linezolid in bacterial cells. In support of a role for MGO, preliminary experiments conducted by Raimkulov $(2019)^{28}$ demonstrated that 5\% manuka honey (Comvita Medihoney ${ }^{\circledR}$ Wound gel) or MGO $(27.5 \mu \mathrm{g} / \mathrm{mL})$ in tryptone soya agar (TSA) plates enhanced the zone of inhibition induced by rifampicin discs against a clinical isolate of MRSA in comparison to TSA plates containing an artificial honey solution. In the same experiments, Activon medical grade manuka honey (Advancis Medical, UK) and two Kazakhstan honeys (buckwheat and buckwheat and multifloral) did not enhance the activity of rifampicin against MRSA. $^{28}$ Similarly, 8 local honeys from the Muscat area of Oman, did not enhance the antimicrobial activity of amoxicillin $(10 \mu \mathrm{g})$ or clarithromycin $(15 \mu \mathrm{g})$ when $50 \mu \mathrm{L}$ of $100 \%$ honey and antibiotics were placed on Helicobacter pylori inoculated agar plates at various distances apart. ${ }^{29}$

Synergistic effects of sub-inhibitory concentrations $(<8 \% \mathrm{w} / \mathrm{v})$ of manuka honey (Comvita, Ltd) and rifampicin on $S$. aureus biofilm formation and on established biofilms have also been observed in vitro. ${ }^{24,30}$ Interestingly, some antibiotic combinations (clindamycin, gentamicin and oxacillin) showed an antagonistic effect on $S$. aureus established biofilms when the honey was used at sub-inhibitory concentrations but not at higher honey concentrations above the MIC (eg, 16\% w/v). Physiological and metabolic differences in bacteria within a biofilm could impair the ability of sub-inhibitory concentrations of honey in combination with antibiotics to kill the bacteria.

Other researchers support the occurrence of enhanced effects of honey and antibiotics. Klein et al $(2020)^{31}$ used a broth culture assay to investigate the ability of subinhibitory concentrations of a range of medical grade honeys (Comvita ${ }^{\circledR}$ Manuka Medihoney ${ }^{\circledR}$; Comvita ${ }^{\circledR}$ Medihoney ${ }^{\circledR}$ Antibacterial Wound Gel ${ }^{\mathrm{TM}}$; Revamil ${ }^{\mathbb{R}}$ gel; and Surgihoney ${ }^{\mathrm{TM}} \mathrm{RO}^{\circledR}$ ) to enhance the activity of antibiotics (tetracycline, sulphatriad, streptomycin, penicillin G, chloramphenicol and ampicillin) against $S$. aureus and P. aeruginosa. In their study, bacteria were incubated aerobically overnight in broth cultures containing $10 \%$ honey. Samples from these cultures were then spread onto TSA plates and antibiotic discs (Mastring-S, Mast Group Ltd) were added to the agar and incubated at $37^{\circ} \mathrm{C}$. The researchers found that the ability of the honeys to enhance the activity of the antibiotic depended on the type of honey, the antibiotic, and the bacterial species. Their key findings were that Surgihoney ${ }^{\mathrm{TM} R O^{\circledR}}{ }^{\circledR}$ and Comvita ${ }^{\circledR}$ Medihoney ${ }^{\circledR}$ Antibacterial Wound Gel ${ }^{\mathrm{TM}}$ increased the activity of tetracycline and ampicillin against $S$. aureus and increased the activity of tetracycline against $P$. aeruginosa.

There is sufficient evidence to suggest that honey can function synergistically with antibiotics to increase bacterial killing in vitro. The outcome however is influenced by the concentration and the type of honey, the bacterial species or strain, the status of the bacteria, ie, planktonic versus biofilm and the type of antibiotic. Processes are not fully understood but possible mechanisms are suggested in Figure 1. Honey is known to contain a complex mixture of polyphenols each of which could act individually or 


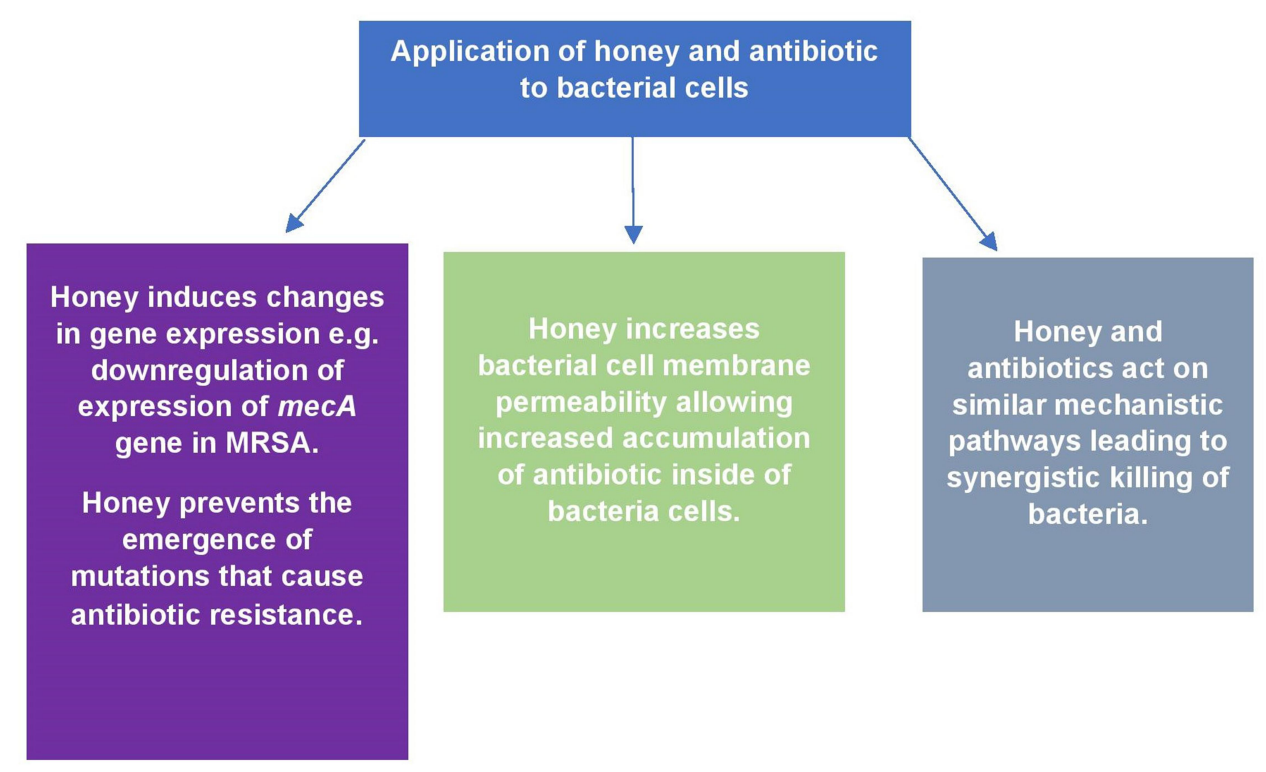

Figure I Possible mechanisms by which honey and antibiotics synergistically kill bacterial cells.

synergistically with other polyphenols or other antimicrobial components to exert diverse biological effects. Furthermore, antibiotic groups kill bacteria via different mechanisms and therefore the interaction of antibiotics with the unique components in different types of honey would likely result in diverse outcomes. Polyphenols may be important in the synergistic interactions of honey and antibiotics, but their role requires further investigation. Table 3 summarises key research findings on the antimicrobial effects in vitro of honey and antibiotic combinations.

\section{Honey and Antibiotics: In vivo Studies}

Studies specifically investigating synergistic effects of honey and antibiotic combinations in vivo are lacking. One study by Mat Lazim et al $(2012)^{32}$ involved the use of tualang honey and the antibiotic sultamicillin for the treatment of wounds occurring after tonsillectomy. An open labelled prospective randomised clinical trial involving two treatment groups was conducted. In the first group, 35 tonsillectomy patients (average age of 9) received intra-operative oral administration of $3 \mathrm{mls}$ of tualang honey and then post-operative oral administration of $4 \mathrm{mls}$ of tualang honey 3 times daily for seven days. In addition to the honey treatment, group 1 also received intravenous $25 \mathrm{mg} / \mathrm{kg}$ sultamicillin three times daily for 2 days and then oral sultamicillin two times daily for 5 days. In group 2, 28 tonsillectomy patients (average age 11) were treated with the antibiotic regime only. The authors reported that wound healing was significantly faster in the honey and antibiotic treated group in comparison to the antibiotic only treated group. Case reports also exist, for example, one report of a diabetic patient with a chronic ulcer on the right lower limb described successful healing following treatment with honey dressings, systemic antibiotic therapy, surgical toilet, and skin graft. ${ }^{33}$ Similarly, another case study reported on the successful healing of a deep diabetic foot ulcer in a 38-year-old female patient treated with intravenous antibiotics (metronidazole and ceftriaxone), surgical debridement and daily dressings covered with trigona honey (harvested from the Borneo jungle). ${ }^{34}$

Clearly more research that specifically investigates the combined effects of honey and antibiotics in vivo is required to fully determine clinical effectiveness. It is also important to consider how honey and antibiotics should be administered clinically to maximise synergistic or additive effects. In wound management, an antibiotic may be administered systemically facilitating entry from the base of the wound, whilst honey is administered topically, reaching the upper surface of the wound. In diabetic patients, the ability of systemically administered antibiotics to reach the wound may be impaired due to poor circulation. An alternative approach may be to administer both the honey and the antibiotic topically. Another factor to consider is the concentration of honey to use. In wound healing, high concentrations of honey $(>90 \% \mathrm{w} / \mathrm{v})$ are commonly used, yet many of the experiments investigating 
Table 3 Summary of the Key in vitro Findings of the Antimicrobial Activity of Honey and Antibiotic Combinations

\begin{tabular}{|c|c|c|c|c|c|}
\hline Type of Honey & Antibiotic & Method & $\begin{array}{l}\text { Micro- } \\
\text { Organism }\end{array}$ & Key Findings & Reference \\
\hline Manuka honey $(5 \%$ w/v) & Oxacillin & $\begin{array}{l}\text { Disc diffusion, } \\
\text { E-test strip, broth } \\
\text { dilution, } \\
\text { chequerboards, } \\
\text { growth curves. }\end{array}$ & MRSA & $\begin{array}{l}\text { Synergistic antimicrobial activity against } \\
\text { MRSA and reversal of oxacillin } \\
\text { resistance. }\end{array}$ & 23 \\
\hline $\begin{array}{l}\text { Manuka honey } \\
\text { (Manukacare, } 18+\text {, } \\
\text { Comvita), }(5 \% \mathrm{w} / \mathrm{v})\end{array}$ & 15 antibiotics & $\begin{array}{l}\text { Disc diffusion, } \\
\text { E-test strip, broth } \\
\text { dilution, } \\
\text { chequerboards, } \\
\text { growth curves. }\end{array}$ & $\begin{array}{l}\text { MRSA } \\
\text { P. aeruginosa }\end{array}$ & $\begin{array}{l}\text { Synergistic antimicrobial activity against } \\
\text { MRSA for manuka honey and } \\
\text { tetracycline, imipenem and mupirocin } \\
\text { combinations and additive activity } \\
\text { against } P \text {. aeruginosa for manuka honey } \\
\text { and tetracycline, rifampicin and colistin } \\
\text { combinations. }\end{array}$ & 26 \\
\hline $\begin{array}{l}\text { Medihoney (Comvita } \\
\text { Ltd) } \\
5 \%, 7 \% \mathrm{w} / \mathrm{v}\end{array}$ & Rifampicin & $\begin{array}{l}\text { Disc diffusion } \\
\text { assay, } \\
\text { chequerboards, } \\
\text { time kill curves. }\end{array}$ & $\begin{array}{l}\text { MRSA, clinical } \\
\text { isolates of } \\
\text { S. aureus. }\end{array}$ & $\begin{array}{l}\text { Synergistic antimicrobial activity of } \\
\text { Medihoney and rifampicin combination } \\
\text { against MRSA and clinical isolates of } \\
\text { S. aureus. }\end{array}$ & 25 \\
\hline $\begin{array}{l}\text { Manuka honey } \\
\text { (Comvita Ltd) }(<8 \%)\end{array}$ & $\begin{array}{l}\text { Rifampicin, oxacillin, } \\
\text { gentamicin, } \\
\text { clindamycin }\end{array}$ & $\begin{array}{l}\text { Disc diffusion } \\
\text { assay, } \\
\text { chequerboards }\end{array}$ & $\begin{array}{l}\text { Strains of } \\
\text { S. aureus } \\
\text { (planktonic } \\
\text { growth and } \\
\text { biofilm } \\
\text { formation) }\end{array}$ & $\begin{array}{l}\text { Rifampicin and manuka honey } \\
\text { considered to be most effective as } \\
\text { demonstrated synergistic antimicrobial } \\
\text { activity against all tested strains } \\
\text { including planktonic bacteria and } \\
\text { S. aureus biofilm formation. } \\
\text { Clindamycin or oxacillin manuka honey } \\
\text { combinations demonstrated synergistic } \\
\text { antimicrobial activity against most } \\
\text { strains (planktonic and biofilm } \\
\text { formation) but not all. } \\
\text { Gentamicin and manuka honey } \\
\text { combinations demonstrated an additive } \\
\text { antimicrobial effect. }\end{array}$ & 24 \\
\hline $\begin{array}{l}\text { Manuka honey } \\
\text { (Medihoney, Comvita } \\
\text { Ltd) } \\
\text { (inhibitory and } \\
\text { subinhibitory } \\
\text { concentrations tested). }\end{array}$ & $\begin{array}{l}\text { Rifampicin, fusidic } \\
\text { acid, } \\
\text { clindamycin, } \\
\text { gentamicin, oxacillin. }\end{array}$ & $\begin{array}{l}\text { Checkerboard } \\
\text { microdilution } \\
\text { assays, viability } \\
\text { assays, MacSynergy } \\
\text { II analysis. }\end{array}$ & $\begin{array}{l}\text { S. aureus, } \\
\text { established } \\
\text { biofilm }\end{array}$ & $\begin{array}{l}\text { Most effective combination against } \\
\text { established S. aureus biofilms was } \\
\text { rifampicin and Medihoney. Fusidic acid } \\
\text { and Medihoney combination induced } \\
\text { some synergistic antimicrobial effects. } \\
\text { Clindamycin, gentamicin, and oxacillin } \\
\text { Medihoney combinations induced } \\
\text { antagonistic effects against } S \text {. aureus } \\
\text { established biofilms when honey was } \\
\text { used at sub-inhibitory concentrations } \\
\text { but not at inhibitory concentrations. }\end{array}$ & 30 \\
\hline $\begin{array}{l}\text { Manuka honey (Manuka } \\
\text { Health, NZ) (5\%) }\end{array}$ & Linezolid & $\begin{array}{l}\text { Disc diffusion } \\
\text { assay }\end{array}$ & $\begin{array}{l}\text { MRSA and } \\
\text { MSSA strains } \\
\text { of S. aureus }\end{array}$ & $\begin{array}{l}\text { Manuka honey increases the sensitivity } \\
\text { of MRSA and MSSA to linezolid. }\end{array}$ & 27 \\
\hline
\end{tabular}

(Continued) 
Table 3 (Continued).

\begin{tabular}{|c|c|c|c|c|c|}
\hline Type of Honey & Antibiotic & Method & $\begin{array}{l}\text { Micro- } \\
\text { Organism }\end{array}$ & Key Findings & Reference \\
\hline $\begin{array}{l}\text { Four medical grade } \\
\text { honeys: I. Comvita }{ }^{\circledR} \\
\text { Manuka Medihoney } \\
\text { 2. } \\
\text { Comvita }^{\circledR} \text { Medihoney } \\
\text { Antibacterial Wound } \\
\text { Gel }^{\circledR M} \\
\text { 3. Revamil } \\
\text { 4.Surgihoney }{ }^{\circledR M}{ }^{\mathrm{TM}} \mathrm{RO}^{\circledR}\end{array}$ & $\begin{array}{l}\text { Tetracycline, } \\
\text { sulphatriad, } \\
\text { streptomycin, } \\
\text { penicillin G, } \\
\text { chloramphenicol and } \\
\text { ampicillin. }\end{array}$ & $\begin{array}{l}\text { Broth culture } \\
\text { assay }\end{array}$ & $\begin{array}{l}\text { S. aureus } \\
\text { P. aeruginosa }\end{array}$ & $\begin{array}{l}\text { Surgihoney }{ }^{\mathrm{TM}} \mathrm{RO}^{\circledR} \text { and } \\
\text { Comvita }{ }^{\circledR} \text { Medihoney }^{\circledR} \text { Antibacterial } \\
\text { Wound Gel } \mathrm{I}^{\mathrm{TM}} \text { increased the sensitivity } \\
\text { of S. aureus to tetracycline and } \\
\text { ampicillin. } \\
\text { Comvita }{ }^{\circledR} \text { Manuka Medihoney }{ }^{\circledR} \text { did not } \\
\text { enhance the sensitivity of S. aureus to } \\
\text { any of the antibiotics tested. } \\
\text { Comvita }{ }^{\circledR} \text { Medihoney }{ }^{\circledR} \text { Antibacterial } \\
\text { Wound Gel }{ }^{\mathrm{TM}} \text {, Comvita }{ }^{\circledR} \text { Manuka } \\
\text { Medihoney }{ }^{\circledR} \text { and Surgihoney }{ }^{\mathrm{TM}} \mathrm{RO}^{\circledR} \\
\text { enhanced the sensitivity of } P \text {. aeruginosa } \\
\text { to tetracycline. } \\
\text { Whether the enhanced antimicrobial } \\
\text { effects were synergistic, or additive was } \\
\text { not determined in this study. }\end{array}$ & 31 \\
\hline
\end{tabular}

synergistic effects of honey and antibiotics in vitro have used low subinhibitory concentrations of honey, eg, $5 \% \mathrm{w} /$ v. Furthermore, despite the general belief that bacterial resistance to honey does not occur there is one study that suggests that resistance is possible. Camplin and Maddocks (2014) demonstrated that $P$. aeruginosa biofilms treated with manuka honey (Medihoney, Comvita) developed increased resistance to manuka honey and to the antibiotic's imipenem and rifampicin, as demonstrated by an increase in minimal inhibitory concentration (MIC) in recovered isolates. ${ }^{35}$ The resistance was suggested to be due to small colony variants and the authors suggested that in clinical practice medical honey should be administered for a sufficient period of time and in combination with other antimicrobials so that the infection is sufficiently cleared and the chances of resistance reduced. In vivo clinical studies are needed to fully understand the combined effects of honey and antibiotics in wound management and to determine treatment protocols that optimise synergistic or additive interactions and healing.

\section{Honey and Other Natural Agents: In vitro Studies}

In vitro research has also examined the antimicrobial effects of combining honey and other natural agents such as ginger, royal jelly, propolis and vitamins. Ewnetu et al (2014) $)^{36}$ reported that mixtures of Ethiopian honey and ginger extracts $(50 \% \mathrm{v} / \mathrm{v})$ had superior antimicrobial activity than ginger extract $(50 \% \mathrm{v} / \mathrm{v})$ or honey alone $(50 \% \mathrm{v} / \mathrm{v})$ in a well diffusion assay against E. coli, Staphylococcus aureus (MRSA), and antibiotic-resistant strains of E. coli and $K$. pneumoniae. Reportedly, the honey and ginger extract combination induced larger zones of inhibition than standard antibiotic discs. Boukraa $(2008)^{37}$ described enhanced effects of subinhibitory concentrations of Algerian honeys (orange blossom and eucalyptus) when combined with royal jelly against $P$. aeruginosa. For example, when compared with the MIC of honey alone there was a considerable decrease $(\sim 90 \%)$ in the MIC when honey $(1 \% \mathrm{v} / \mathrm{v})$ was combined with $3 \%$ royal jelly. Al-Waili et al $(2012)^{38}$ using broth macro-dilution reported synergistic effects of subinhibitory concentrations of sumra honey from Saudi Arabia when combined with subinhibitory concentrations of propolis against $S$. aureus, E. coli $C$. albicans and mixed microbial cultures. The MICs of honey and propolis combinations were lower than honey and propolis alone against all micro-organisms tested in the study. Propolis obtained from Saudi Arabia demonstrated superior synergistic effects in comparison to propolis obtained from Egypt suggesting that the type of propolis is important. In a short communication by Kowalski and Makarewicz (2017) ${ }^{39}$ honey supplemented with $1 \%$ propolis demonstrated higher antibacterial activity than honey alone against $E$. coli in a well diffusion assay. Similarly, Oses et al $(2016)^{40}$ 
reported synergistic antimicrobial effects of honeys from Spain against $E$. coli, $S$. aureus and P. aeruginosa in a disc diffusion assay when ethanol extracts of propolis $(0.1 \%$, $0.3 \%$ or $0.5 \%$ ) were added to the undiluted honey. Furthermore, the anti-inflammatory effects of the honey (75\%), measured using a hyaluronidase inhibition assay, were enhanced when propolis ethanol extracts were added. Honey has also been combined with other natural agents including cinnamaldehyde found in cinnamon and carvacrol, a monoterpene found in thyme. The combination of honey obtained from Damavand district Iran, with subMIC concentrations of cinnamaldehyde and carvacrol had greater antibacterial activity than honey alone against suspensions of clinical isolates of $P$. aeruginosa ${ }^{41}$ This triple combination was also reported to reduce the expression of exoS gene involved in $P$. aeruginosa virulence and ampC gene involved in $P$. aeruginosa resistance to antibiotics such as carbapenems and monobactams. Even more complex mixtures of natural agents have been tested. For example, Dashtdar et al $2016^{42}$ prepared a gel composed of herbal extracts of Acacia catechu, Castanea sativa, Ephedra sinica and Momia combined with honey (25\%), maple saps, Phoenix dactylifera (date), pomegranate extract and Azadirachta indica gum. This gel had a higher antibacterial activity in an agar well diffusion assay than the antibiotic cloxacillin or honey alone against $P$. aeruginosa. Natural bioactive agents such as vitamins have also been combined with honey and antimicrobial activity assessed. Majtan et al $(2020)^{43}$ investigated the antimicrobial activity of Slovakian honeys and a commercially available UMF 15+ manuka honey (Natures Nectar, UK) supplemented with sub-MIC concentrations of vitamin $\mathrm{C}$ in an MIC assay against bacterial isolates including $P$. aeruginosa and $S$. aureus. The antimicrobial activity of honey vitamin C combination was also assessed against $P$. aeruginosa, S. aureus, S. agalactiae and E. faecalis multi-species biofilms. Their key findings were that supplementation of honey with sub-MIC concentrations of vitamin $\mathrm{C}$ reduced the MIC of all types of honey against planktonic preparations of $P$. aeruginosa. In contrast, supplementation of honeydew honey with sub-MIC concentrations of vitamin C increased the MIC against planktonic S. aureus. Honeydew honey $(100 \%)$ supplemented with vitamin C (100mg/g of honey) had superior antibiofilm activity than honey alone and caused clearance of all the bacterial species within the biofilm after 48 hours. Vitamin $\mathrm{C}$ is reported to have antibacterial activity and the authors suggested that the antibacterial effects of honey and vitamin
C combination may be due to increased production of reactive oxygen species in bacterial cells. In another study, L-Mesitran, a medical honey formulation containing $40 \%$ Mexican yucatan honey and vitamins $\mathrm{C}$ and $\mathrm{E}$ was reported to have anti-fungal activity against Candida albicans whilst $40 \%$ Mexican yucatan honey alone did not. ${ }^{44}$ The authors suggested that the vitamins or other components in the L-Mesitran formulation may be enhancing the antifungal activity of the honey. Furthermore, L-Mesitran formulation was found to have superior antimicrobial activity against Staphylococcus pseudintermedius, a cause of canine pyoderma, and Malassezia pachydermatis in comparison to the honey component of L-Mesitran only. ${ }^{45}$ The authors again concluded that other components in the L-Mesitran formulation which include medical grade hypoallergenic lanolin, propylene glycol, polyethylene glycol 4000 and vitamins $\mathrm{C}$ and $\mathrm{E}$ may be enhancing the antimicrobial activity of the honey.

Synergism between honey and other natural agents could be due to interactions between constituent polyphenols or both substances may be acting on similar mechanistic pathways leading to an enhanced biological effect. Table 4 summarises key research findings on the antimicrobial effects in vitro of honey and natural agent combinations.

\section{Honey and Other Natural Agents: In vivo Studies}

Again, few studies have specifically investigated the therapeutic effects of honey combined with other natural agents in vivo. One case report by Lofty et al (2006) ${ }^{46}$ described the case of a 65 -year-old diabetic male patient with a deep infected wound on the foot. The patient was treated with systemic antibiotics; metronidazole (1500 mg per day) and combined amoxicillin with clavulanic acid (1500 mg/day) for 10 days. Thereafter, ciprofloxacin $(1500 \mathrm{mg} /$ day) was used. Healing of the wound reportedly improved significantly when the wound was treated topically every day with a paste containing $800 \mathrm{mg}$ of bee propolis and $50 \mathrm{~g}$ of myrrh mixed with honey. In a prospective, open-label block randomised controlled clinical study conducted in horses it was found that intralesional application of L-Mesitran to wounds prior to wound closure improved healing and reduced infection (data from 69 horses) in comparison to wounds that were not treated with L-Mesitran (data from 58 horses). ${ }^{47}$ Furthermore, Nair et al (2020) reported on the successful 
Table 4 Summary of the Key in vitro Findings of the Antimicrobial Activity of Honey and Natural Agent Combinations

\begin{tabular}{|c|c|c|c|c|c|}
\hline $\begin{array}{l}\text { Type of } \\
\text { Honey }\end{array}$ & Natural Agent & Method & Micro-Organism & Key Findings & Reference \\
\hline $\begin{array}{l}\text { Ethiopian } \\
\text { honey } \\
(50 \% \mathrm{v} / \mathrm{v})\end{array}$ & $\begin{array}{l}\text { Ginger extracts }(50 \% \mathrm{v} / \mathrm{v}) \\
\text { Prepared honey ginger mixture }(50 \% \\
\mathrm{v} / \mathrm{v}) \text {. }\end{array}$ & $\begin{array}{l}\text { Agar well } \\
\text { diffusion } \\
\text { assay, broth } \\
\text { assay. }\end{array}$ & $\begin{array}{l}\text { S. aureus, MRSA, } \\
\text { E. coli (sensitive and } \\
\text { resistant strains). } \\
\text { K. pneumoniae } \\
\text { (resistant) }\end{array}$ & $\begin{array}{l}\text { Honey and ginger combination } \\
\text { induced higher mean zones of } \\
\text { inhibition than honey or ginger alone } \\
\text { or standard antibiotic discs } \\
\text { (methicillin, penicillin, amoxicillin). }\end{array}$ & 36 \\
\hline $\begin{array}{l}\text { Algerian } \\
\text { honey } \\
\text { (orange } \\
\text { blossom, } \\
\text { eucalyptus) }\end{array}$ & $\begin{array}{l}\text { Royal jelly (sub- MIC } \\
\text { concentrations) }(3 \%(\mathrm{v} / \mathrm{v}) ; 2 \%(\mathrm{v} / \mathrm{v}) \text {; } \\
\text { I\% (v/v) added to honey). }\end{array}$ & MIC assay & P. aeruginosa & $\begin{array}{l}\text { For each honey type there was }>90 \% \\
\text { decrease in the MIC when } 3 \%(\mathrm{v} / \mathrm{v}) \\
\text { royal jelly was added; a } 66.6 \% \\
\text { decrease when } 2 \%(\mathrm{v} / \mathrm{v}) \text { royal jelly } \\
\text { was added and a } 50 \% \text { decrease in MIC } \\
\text { when } 1 \%(\mathrm{v} / \mathrm{v}) \text { royal jelly was added. }\end{array}$ & 37 \\
\hline $\begin{array}{l}\text { Saudi } \\
\text { Arabian } \\
\text { sumra } \\
\text { honey } \\
\text { (Acacia } \\
\text { tortilis) }\end{array}$ & $\begin{array}{l}\text { Ethyl alcohol extract of propolis } \\
\text { (Egyptian and Saudi Arabian) (sub } \\
\text { MIC concentrations) }\end{array}$ & MIC assay & $\begin{array}{l}\text { S. aureus, E. coli, } \\
\text { C. albicans, } \\
\text { polymicrobial } \\
\text { cultures. }\end{array}$ & $\begin{array}{l}\text { The MIC of honey and propolis } \\
\text { combined was lower than honey or } \\
\text { propolis alone. }\end{array}$ & 38 \\
\hline $\begin{array}{l}\text { Polish } \\
\text { honey } \\
\text { (lime) } \\
(75 \% \mathrm{w} / \mathrm{w})\end{array}$ & Ethanol extract of propolis ( $1 \%$ ), & $\begin{array}{l}\text { Agar well } \\
\text { diffusion } \\
\text { assay }\end{array}$ & E. coli & $\begin{array}{l}\text { Larger zones of inhibition were seen } \\
\text { when honey was enriched with I\% } \\
\text { propolis. }\end{array}$ & 39 \\
\hline $\begin{array}{l}\text { Spanish } \\
\text { honeys } \\
\text { (heather, } \\
\text { chestnut } \\
\text { and } \\
\text { multifloral) }\end{array}$ & $\begin{array}{l}\text { Ethanol extracts of propolis }(0.1,0.3 \\
\text { or } 0.5 \%) \text { harvested from Spain. }\end{array}$ & $\begin{array}{l}\text { Agar } \\
\text { diffusion } \\
\text { assay }\end{array}$ & $\begin{array}{l}\text { Microorganisms } \\
\text { including E. coli, } \\
\text { S. aureus, } \\
\text { P. aeruginosa. }\end{array}$ & $\begin{array}{l}\text { In general, enhanced antimicrobial } \\
\text { activity was observed when honey } \\
\text { was supplemented with propolis. The } \\
\text { increase varied depending on the type } \\
\text { of honey, concentration of propolis } \\
\text { and test micro-organism. }\end{array}$ & 40 \\
\hline $\begin{array}{l}\text { Iranian } \\
\text { honey from } \\
\text { Damavand } \\
\text { district, } \\
\text { Iran. }\end{array}$ & $\begin{array}{l}\text { Cinnamaldehyde and carvacrol (sub- } \\
\text { MIC concentrations) }\end{array}$ & $\begin{array}{l}\text { Broth } \\
\text { dilution } \\
\text { method }\end{array}$ & P. aeruginosa & $\begin{array}{l}\text { The MIC of the combination of } \\
\text { honey, cinnamaldehyde and carvacrol } \\
\text { was lower than honey alone }(0.49 \mu \mathrm{g} / \\
\mathrm{mL} \text { vs } I I 4.2 \mu \mathrm{g} / \mathrm{mL} \text { respectively). The } \\
\text { antibacterial activity of the triple } \\
\text { combination was reportedly greater } \\
\text { than imipenem. }\end{array}$ & 41 \\
\hline $\begin{array}{l}\text { Iranian } \\
\text { honey } \\
\text { (25\%) from } \\
\text { Fasa, Iran }\end{array}$ & $\begin{array}{l}\text { Gel composed of herbal extracts of } \\
\text { Acacia catechu, Castanea sativa, } \\
\text { Ephedra sinica and Momia combined } \\
\text { with honey ( } 25 \%) \text {, maple saps, } \\
\text { Phoenix dactylifera (date), } \\
\text { pomegranate extract and Azadirachta } \\
\text { indica gum }\end{array}$ & $\begin{array}{l}\text { Agar well } \\
\text { diffusion } \\
\text { assay }\end{array}$ & P. aeruginosa & $\begin{array}{l}\text { Zone of inhibition induced by the } \\
\text { herbal gel formulation was greater } \\
\text { than honey alone ( } 35.1 \mathrm{~mm} \text { vs } \\
13.1 \mathrm{~mm} \text { respectively). }\end{array}$ & 42 \\
\hline
\end{tabular}

(Continued) 
Table 4 (Continued).

\begin{tabular}{|c|c|c|c|c|c|}
\hline $\begin{array}{l}\text { Type of } \\
\text { Honey }\end{array}$ & Natural Agent & Method & Micro-Organism & Key Findings & Reference \\
\hline $\begin{array}{l}\text { Slovakian } \\
\text { honeys } \\
\text { (sunflower, } \\
\text { acacia and } \\
\text { honeydew) } \\
\text { UMF I5+ } \\
\text { manuka } \\
\text { honey } \\
\text { (Natures } \\
\text { Nectar, UK) }\end{array}$ & $\begin{array}{l}\text { Vitamin C } \\
\text { (Sub-inhibitory concentrations) }\end{array}$ & $\begin{array}{l}\text { MIC assay } \\
\text { Biofilm } \\
\text { wound } \\
\text { model }\end{array}$ & $\begin{array}{l}\text { Planktonic bacteria } \\
\text { including } \\
\text { P. aeruginosa and } \\
\text { S. aureus. } \\
\text { Multispecies } \\
\text { biofilms } \\
\text { (P. aeruginosa, } \\
\text { S. aureus, } \\
\text { S. agalactiae, } \\
\text { E. faecalis) }\end{array}$ & $\begin{array}{l}\text { Supplementation of honey with } \\
\text { vitamin C reduced the MIC of all } \\
\text { honey types tested against planktonic } \\
\text { P. aeruginosa. Supplementation of } \\
\text { honeydew honey with vitamin } \\
\text { C increased the MIC against } \\
\text { planktonic S. aureus. } \\
\text { Honeydew honey supplemented with } \\
\text { vitamin C (I00mg/g) had superior } \\
\text { antibiofilm activity than honey alone. }\end{array}$ & 43 \\
\hline $\begin{array}{l}\text { Mexican } \\
\text { yucatan } \\
\text { honey } \\
\text { (L-Mesitran) }\end{array}$ & $\begin{array}{l}\text { Vitamins } \mathrm{C} \text { and } \mathrm{E} \\
\text { (L-Mesitran contains } 40 \% \text { Mexican } \\
\text { yucatan honey and vitamins } \mathrm{C} \text { and } \mathrm{E} \text { ) }\end{array}$ & $\begin{array}{l}\text { Antifungal } \\
\text { MIC } \\
\text { method for } \\
\text { yeasts }\end{array}$ & C. albicans & $\begin{array}{l}\text { L-Mesitran demonstrated antifungal } \\
\text { activity against C. albicans (MIC } 25 \%- \\
50 \% \text { ), whereas } 40 \% \text { Mexican yucatan } \\
\text { honey did not. }\end{array}$ & 44 \\
\hline $\begin{array}{l}\text { Mexican } \\
\text { yucatan } \\
\text { honey } \\
\text { (L-Mesitran) }\end{array}$ & $\begin{array}{l}\text { Vitamins } \mathrm{C} \text { and } \mathrm{E} \\
\text { (L-Mesitran contains } 40 \% \text { Mexican } \\
\text { yucatan honey and vitamins } \mathrm{C} \text { and } \mathrm{E} \text { ) }\end{array}$ & $\begin{array}{l}\text { Microbroth } \\
\text { assay to } \\
\text { determine } \\
\text { MBC }\end{array}$ & $\begin{array}{l}\text { Staphylococcus } \\
\text { pseudintermedius, } \\
\text { Malassezia } \\
\text { pachydermatis }\end{array}$ & $\begin{array}{l}\text { L-Mesitran had lower MBC in } \\
\text { comparison to the honey component } \\
\text { of L-Mesitran only. }\end{array}$ & 45 \\
\hline
\end{tabular}

healing of diabetic foot ulcers (six patients) following topical application of L-Mesitran. ${ }^{48}$ The wounds had previously failed to respond to a range of other treatments including antibiotics. Another case study reported on successful eradication of infection in an MRSA infected titanium mesh in an incisional hernia in a 70-year-old female patient treated with L-Mesitran. ${ }^{49}$ The honey formulation was applied to the wound cavity and covered with gauze daily. More studies conducted in humans are needed to fully determine the efficacy of the combination of honey and other natural agents for the treatment of skin and wound infections.

\section{Honey and Other Therapies (in vitro and in vivo Studies)}

Other therapeutic agents being considered for use in combination with honey for the treatment of wounds include honey and bacteriophage therapy, honey supplemented with antimicrobial peptides, honey combined with cyclodextrins or hydrogel, or honey and laser therapy. Novel approaches to wound healing have involved adding a combination of antimicrobial agents to nanofibrous scaffolds. For example, Sarhan and Azzazy (2017) ${ }^{50}$ reported that honey (Egyptian clover) (30\%) chitosan nanofibers loaded with bee venom $(0.01 \%)$ and bacteriophages had superior antimicrobial activity in a broth culture assay against MDR $P$. aeruginosa in comparison to ionic silver containing Aquacel-Ag wound dressing. Furthermore, the novel honey bacteriophage dressing demonstrated better wound healing ability in mice when compared to Aquacel$\mathrm{Ag}$ wound dressing. Oliveira et al $(2017)^{51}$ also reported synergistic antimicrobial effects against $E$. coli biofilms formed on 96 well plates at 12 and 24 hours using multifloral Portuguese honey and an E. coli specific bacteriophage. This approach combines the antibiofilm effects of honey with the ability of bacteriophages to lyse bacteria. Scanning electron microscopy revealed that honey caused perturbations in the membrane of the E. coli whilst the bacteriophage caused complete lysis with only vesicle structures left behind.

Kwakman et al (2011) ${ }^{52}$ investigated the antimicrobial effects of supplementing Revamil honey with the antimicrobial peptides LL-37 and the synthetic peptide bacterial peptide 2 (BP2). They reported that the antimicrobial activity of LL-37 was inhibited in the presence of honey, but this was not the case for BP2. Using a liquid bactericidal assay, it was shown that Revamil honey supplemented with $75 \mu \mathrm{M}$ BP2 had more rapid antibacterial activity against MRSA and extended spectrum $\beta$ lactamase 
(ESBL) E. coli and had a broader spectrum of antibacterial activity than Revamil alone. The authors considered supplementing the honey with hydrogen peroxide or MGO but were concerned that high levels of these components may not be biocompatible.

Hydrogel is commonly used as a wound dressing. It is composed of polymers suspended in water and is thought to provide hydration to a wound and promote healing. ElKased et al $(2017)^{53}$ reported that an Egyptian honey (75\%) chitosan hydrogel formula had superior antimicrobial activity against $P$. aeruginosa, $S$. aureus, $K$. pneumonia and Streptococcus pyogenes in a disc diffusion assay in comparison to pure honey. For example, the mean zone of inhibition for the honey $75 \%$ chitosan hydrogel formula against $S$. aureus was $20.2 \pm 0.4$ vs $15.1 \pm 0.9$ for honey. This formula was also superior to pure honey in the healing of $10 \mathrm{~mm}$ burn wounds induced in mice using a heated metallic rod. The wounds were treated with either the honey $75 \%$ chitosan hydrogel formula or honey for 9 days. By day 9, the honey chitosan treated wounds had a mean diameter of $3.8 \pm 0.2 \mathrm{~mm}$ versus $5.3 \pm 0.8 \mathrm{~mm}$ in the honey only treated group. Furthermore, an alginatebased honey hydrogel containing thymol-based honey from Damavand, Iran was reported to have superior wound healing ability in rats with infected burn wounds than honey alone. ${ }^{54}$ Wound healing was faster in the alginate-based honey hydrogel treated group in comparison to the honey only group. In another study, a paste composed of carboxymethyl cellulose hydrogel (50\%), water (30\%) and chestnut honey $(20 \%)$ had superior antimicrobial activity against $S$. aureus and E.coli in a disc diffusion assay than a paste composed of carboxymethyl cellulose hydrogel $(50 \%)$ and water only. ${ }^{55}$ Furthermore, the paste containing $20 \%$ chestnut honey had superior wound healing ability in comparison to the paste without honey in the treatment of wounds inflicted in the dorsal skin of mice. Tavaloki and Tang (2017) ${ }^{56}$ designed a wound dressing consisting of a high concentration of honey, polyvinyl alcohol hybrid hydrogel and borax as a crosslinking agent. High concentrations of honey are important for wound healing but can negatively affect the physicochemical properties of hybrid hydrogels. The use of borax apparently overcomes this problem and permits the incorporation of high concentrations of honey without negative effects.

Alpha-cyclodextrin is an oligosaccharide that has also been complexed with manuka honey in a formulation named Manuka honey with Cyclopower ${ }^{\mathrm{TM}}$ and supplied by Manuka Health New Zealand Ltd. Using MIC, MBC and time course experiments Manuka honey with Cyclopower ${ }^{\mathrm{TM}}$ was found to have improved bacteriostatic activity against $S$. aureus, MRSA and P. aeruginosa in comparison to uncomplexed manuka honey also supplied by the same company. ${ }^{57}$

Researchers have also explored the use of honey combined with laser treatment for wound healing. Yadav et al $(2018)^{58}$ investigated the combined effect of medical grade manuka honey (Medihoney, Derma Sciences Inc.) and $904 \mathrm{~nm}$ super pulsed laser treatment on the healing of full-thickness burn wounds induced in rats. The wound healing effects of pulsed laser therapy in the red and near infrared spectrum is not fully understood, but it has been suggested that photon energy from this wavelength is absorbed by chromophores in the skin leading to modulation of transcription factors, changes in protein synthesis and enhanced cell proliferation and survival. Combining the antimicrobial effects of honey with the wound healing effects of laser therapy is a unique and novel approach to wound healing. In their study, 4 groups of 6 rats were used. In group 1, wounds were treated with super pulsed $904 \mathrm{~nm}$ laser treatment, 0.2 $\mathrm{J} / \mathrm{cm}^{2}$ daily for seven consecutive days post wound. Group 2 wounds were treated with honey (applied topically over the surface of the wound, 1-hour post burn wound, and daily for 7 consecutive days post wound). Group 3 wounds were treated with a combination of the super pulsed $904 \mathrm{~nm}$ laser treatment regime and the honey regime, whilst group 4 wounds were left untreated. The findings demonstrated that the group that received the combination therapy had enhanced wound closure, as measured using image $\mathrm{J}$ software, and evidence of lower levels of inflammation indicated by lower levels of TNF- $\alpha, I L-1 \beta$ and COX-2 protein expression in the wound tissue in comparison to the other groups.

Rudzka-Nowak et al (2010) ${ }^{59}$ reported on the case of a 55-year-old woman with inflamed and necrotic lesions in the abdominal integuments and lumbar region following rupture of the colon. The wound was infected with E. coli, K. pneumoniae, $P$. aeruginosa, and A. baumannii. The patient was treated with antibiotics linezolidum and metronidazole and then with manuka honey activon tulle dressings (replaced on alternate days) as well as the Genadyne A4 negative pressure wound therapy system. Genadyne A4 provides sub atmospheric pressure across a wound and is reported to reduce swelling, remove wound exudate and bacteria from the wound surface, and stimulate growth of fibroblasts and endothelial cells. Following 3 weeks of 
the combined treatment, the wound healed sufficiently enough for a skin graft to be performed.

\section{Conclusions}

There are several therapeutic agents or therapies that could potentially be combined with honey to enhance antimicrobial activity and wound and skin healing. In vitro studies have investigated the combination of honey with antibiotics, natural agents, eg, propolis, bacteriophages, antimicrobial peptides, laser treatment and hydrogel. The available research suggests that several honey combination therapies have superior antimicrobial activity in comparison to honey alone and in some cases, the effect is synergistic. Honey could be supplemented with other agents as a formulation or as an additional therapy. Honey contains a range of antimicrobial components, including sugar, hydrogen peroxide $\left(\mathrm{H}_{2} \mathrm{O}_{2}\right)$, MGO, polyphenols and antimicrobial peptides. Consideration could be given to supplementing honey with either of these components. However, the combining agent as well as being able to increase antimicrobial activity should be biocompatible and promote re-epithelialisation and wound closure. Therefore, consideration should be given to the potential toxicity of the combining agent as well as the most effective honey to use. Whilst manuka honey has been shown to promote reepithelialisation certain honeys may be more cytotoxic to skin cells than others. Modern delivery methods such as biomimetic nanostructured meshes developed using a layer by layer assembly method allow for a more controlled release of honey that may have lower cytotoxicity and could be more appropriate for the treatment of certain types of wounds or skin lesions. ${ }^{60}$ Modern bioengineering methods have also involved incorporating honey into cryogels. ${ }^{61}$ The $\mathrm{pH}$ of the combining agents used should also be considered as low acidic $\mathrm{pH}$ is thought to be more favourable for wound healing (personal communication, Dr Lorna Fyfe) and attention could also be given to immunomodulatory or antiinflammatory properties. More clinical studies in humans that specifically investigate the effects of honey combination therapies for the treatment of wounds and skin lesions are needed. Future research may involve combining honey with other bioactive agents such as polyphenols, other plant-derived compounds or other agents known to accelerate wound healing such as hyaluronic acid. ${ }^{62}$ Such novel approaches to treatment could be considered not only for wounds but also other types of skin disease. Honey is a relatively cheap substance that could be utilised globally as a combination therapy if efficacy is established.
Furthermore, the reduction or replacement of antibiotic use with other therapies has the potential to lower the risk of development of antibiotic-resistant bacterial strains. Honey combination therapies have the potential to improve clinical outcomes for patients with wound and skin infections and therefore further research in this area should be encouraged.

\section{Author Contributions}

All authors made a significant contribution to the work reported, whether that is in the conception, study design, execution, acquisition of data, analysis and interpretation, or in all these areas; took part in drafting, revising or critically reviewing the article; gave final approval of the version to be published; have agreed on the journal to which the article has been submitted; and agree to be accountable for all aspects of the work.

\section{Funding}

This article was supported by the Ministry of Education and Science, Republic of Kazakhstan; IRN № AP05135293.

\section{Disclosure}

The authors declare no conflict of interest. The funders had no role in the design of the study; in the collection, analyses, or interpretation of data; in the writing of the manuscript, or in the decision to publish.

\section{References}

1. Frykberg RG, Banks J. Challenges in the treatment of chronic wounds. Adv Wound Care (New Rochelle). 2015;4(9):560-582. doi:10.1089/ wound.2015.0635

2. Man E, Hoskins C. Towards advanced wound regeneration. Eur J Pharm Sci. 2020;149:105360. doi:ARTN10536010.1016/j.ejps.2020. 105360

3. WHO. Global report on diabetes 2016. Available from: https://apps. who.int/iris/bitstream/handle/10665/204871/9789241565257_eng.pdf; jsessionid=FC0374540515171C0FB4EE8F46F53BCC? sequence=1. Accessed May 15, 2020.

4. WHO. Obesity and overweight. 2020; Available from: https://www. who.int/en/news-room/fact-sheets/detail/obesity-and-overweight.

Accessed November 2, 2020. 15, 2020.

5. Vestby LK, Gronseth T, Simm R, Nesse LL. Bacterial biofilm and its role in the pathogenesis of disease. Antibiotics (Basel, Switzerland). 2020;9(2):59. doi:10.3390/antibiotics9020059

6. NHS. Dressing formulary and pathways to support wound assessment and management. 2017; Available from: http://www.southstaffordshir ejointformulary.nhs.uk/docs/apg/Wound-Care/SSOTP\%20Pathway\% 20to\%20Support\%20Wound $\% 20$ Assessment $\% 20$ and $\% 20$ Management \%20Nov\%202017.pdf. Accessed October 20, 2019.

7. NHS. Wound dressings and bandages. 2019. Available from: https:// www.ljf.scot.nhs.uk/LothianJointFormularies/Adult/Wound\% 20Section/Pages/default.aspx. Accessed October 20, 2019.. 
8. Coiller M Recognition and management of wound infections. World Wide Wounds. World Wide Wounds. 2004. Available from: http:// www.worldwidewounds.com/2004/january/Collier/Management-ofWoundinfections.html. Accessed October 10, 2019.

9. Irish J, Blair S, Carter DA. The antibacterial activity of honey derived from Australian flora. PLoS One. 2011;6(3):e18229. doi:10.1371/ journal.pone.0018229

10. McLoone P, Warnock M, Fyfe L. Honey: a realistic antimicrobial for disorders of the skin. J Microbiol Immunol Infect. 2016;49 (2):161-167. doi:10.1016/j.jmii.2015.01.009

11. Sherlock O, Dolan A, Athman R, et al. Comparison of the antimicrobial activity of Ulmo honey from Chile and manuka honey against methicillin-resistant Staphylococcus aureus, Escherichia coli and Pseudomonas aeruginosa. BMC Complement Altern Med. 2010;10:47. doi:10.1186/1472-6882-10-47

12. Ranzato E, Martinotti S, Burlando B. Epithelial mesenchymal transition traits in honey-driven keratinocyte wound healing: comparison among different honeys. Wound Repair Regen. 2012;20(5):778-785. doi:10.1111/j.1524-475X.2012.00825.x

13. Rossiter K, Cooper AJ, Voegeli D, Lwaleed BA. Honey promotes angiogeneic activity in the rat aortic ring assay. $J$ Wound Care. 2010;19(10):440,442-446. doi:10.12968/jowc.2010.19.10.79091

14. Tonks A, Cooper R, Jones K, Blair S, Parton J. Honey stimulates inflammatory cytokine production from monocytes. Cytokine. 2003;21:242-247. doi:10.1016/S1043-4666(03)00092-9

15. Majtan J, Kumar P, Majtan T, Walls AF, Klaudiny J. Effect of honey and its major royal jelly protein 1 on cytokine and MMP-9 mRNA transcripts in human keratinocytes. Exp Dermatol. 2010;19(8):e7379. doi:10.1111/j.1600-0625.2009.00994.x

16. Hermanns R, Mateescu C, Thrasyvoulou A, Tananaki C, Wagener FADTG, Cremers NAJ. Defining the standards for medical grade honey. $J$ Apic Res. 2020;59(2):125-135. doi:10.1080/ 00218839.2019 .1693713

17. Jull AB, Cullum N, Dumville JC, Westby MJ, Deshpande S, Walker N. Honey as a topical treatment for wounds. Cochrane Database Syst Rev. 2015;(3):CD005083. doi:10.1002/14651858. CD005083.pub4

18. Dryden M, Lockyer G, Saeed K, Cooke J. Engineered honey: in vitro antimicrobial activity of a novel topical wound care treatment. J Glob Antimicrob Resist. 2014;2(3):168-172. doi:10.1016/j.jgar.2014.03.006

19. Moher D, Liberati A, Tetzlaff J, Altman DG. Preferred reporting items for systematic reviews and meta-analyses: the PRISMA statement. PLoS Med. 2009;6(7):e1000097. doi:10.1371/journal. pmed.1000097

20. Karayil S, Deshpande S, Koppikar G. Effect of honey on multidrug resistant organisms and its synergistic action with three common antibiotics. J Postgrad Med. 1998;44(4):93-96.

21. Al-Jabri AA, Al-Hosni SA, Nzeako BC, Al-Mahrooqi ZH, Nsanze H. Antibacterial activity of Omani honey alone and in combination with gentamicin. Saudi Med J. 2005;26(5):767-771.

22. Abd-El Aal AM, El-Hadidy MR, El-Mashad NB, El-Sebaie AH. Antimicrobial effect of bee honey in comparison to antibiotics on organisms isolated from infected burns. Ann Burns Fire Disasters. 2007;20(2):83-88.

23. Jenkins RE, Cooper R. Synergy between oxacillin and manuka honey sensitizes methicillin-resistant Staphylococcus aureus to oxacillin. $J$ Antimicrob Chemother. 2012;67(6):1405-1407. doi:10.1093/jac/ dks071

24. Liu M, Lu J, Müller P, et al. Antibiotic-specific differences in the response of Staphylococcus aureus to treatment with antimicrobials combined with manuka honey. Front Microbiol. 2014;5:779. doi:10.3389/fmicb.2014.00779

25. Müller P, Alber DG, Turnbull L, et al. Synergism between Medihoney and rifampicin against methicillin-resistant Staphylococcus aureus (MRSA). PLoS One. 2013;8(2):e57679. doi:10.1371/journal. pone. 0057679
26. Jenkins R, Cooper R. Improving antibiotic activity against wound pathogens with manuka honey in vitro. PLoS One. 2012;7(9):e45600. doi:10.1371/journal.pone.0045600

27. Hayes G, Wright N, Gardner SL, Telzrow CL, Wommack AJ, Vigueira PA. Manuka honey and methylglyoxal increase the sensitivity of Staphylococcus aureus to linezolid. Lett Appl Microbiol. 2018;66(6):491-495. doi:10.1111/lam.12880

28. Raimkulov I. An investigation into synergistic effects of Kazakhstan honeys and antibiotics against wound infecting micro-organisms. [dissertation]. Nazarbayev University School of Medicine, NurSultan, Kazakhstan; 2019.

29. Nzeako BC, Al-Namaani F. The antibacterial activity of honey on helicobacter pylori. Sultan Qaboos Univ Med J. 2006;6 (2):71-76

30. Liu MY, Cokcetin NN, Lu J, et al. Rifampicin-manuka honey combinations are superior to other antibiotic-manuka honey combinations in eradicating Staphylococcus aureus biofilms. Front Microbiol. 2017;8:2653. doi:10.3389/fmicb.2017.02653

31. Klein JP, Graves-Morris K, Coyle S, Fyfe L. Inhibition and changes in antibiotic sensitivity of bacteria cultured aerobically and anaerobically in four different medicinal honeys. ES J Clin Med. 2020;1:2.

32. Mat Lazim N, Abdullah B, Salim R. The effect of Tualang honey in enhancing post tonsillectomy healing process. An open labelled prospective clinical trial. Int J Pediatr Otorhinolaryngol. 2013;77 (4):457-461. doi:10.1016/j.ijporl.2012.11.036

33. Teobaldi I, Stoico V, Perrone F, Bruti M, Bonora E, Mantovani A. Honey dressing on a leg ulcer with tendon exposure in a patient with type 2 diabetes. Endocrinol Diabetes Metab Case Rep. 2018;18-0117. doi:10.1530/edm-18-0117

34. Astrada A, Nakagami G, Jais S, Sanada H. Successful treatment of a diabetic foot ulcer with exposed bone using Trigona honey: a case study. J Wound Care. 2019;28(Sup12):S4-s8. doi:10.12968/ jowc.2019.28.Sup12.S4

35. Camplin AL, Maddocks SE. Manuka honey treatment of biofilms of Pseudomonas aeruginosa results in the emergence of isolates with increased honey resistance. Ann Clin Microbiol Antimicrob. 2014;13:19. doi:10.1186/1476-0711-13-19

36. Ewnetu Y, Lemma W, Birhane N. Synergetic antimicrobial effects of mixtures of Ethiopian honeys and ginger powder extracts on standard and resistant clinical bacteria isolates. Evid Based Complement Alternat Med. 2014;562804. doi:10.1155/2014/562804

37. Boukraa L. Additive activity of royal jelly and honey against Pseudomonas aeruginosa. Altern Med Rev. 2008;13(4):330-333.

38. Al-Waili N, Al-Ghamdi A, Ansari MJ, Al-Attal Y, Salom K. Synergistic effects of honey and propolis toward drug multi-resistant Staphylococcus aureus, Escherichia coli and Candida albicans isolates in single and polymicrobial cultures. Int J Med Sci. 2012;9(9):793-800. doi:10.7150/ijms.4722

39. Kowalski S, Makarewicz M. Functional properties of honey supplemented with bee bread and propolis. Nat Prod Res. 2017;31 (22):2680-2683. doi:10.1080/14786419.2017.1286481

40. Osés SM, Pascual-Maté A, Fernández-Muiño MA, López-Díaz TM, Sancho MT. Bioactive properties of honey with propolis. Food Chem. 2016;196:1215-1223. doi:10.1016/j.foodchem.2015. 10.050

41. Mohammadzamani Z, Khorshidi A, Khaledi A, Shakerimoghaddam A, Moosavi GA, Piroozmand A. Inhibitory effects of Cinnamaldehyde, Carvacrol, and honey on the expression of exoS and ampC genes in multidrug-resistant Pseudomonas aeruginosa isolated from burn wound infections. Microb Pathog. 2020;140:103946. doi:10.1016/j. micpath.2019.103946

42. Dashtdar M, Dashtdar MR, Dashtdar B, Khan GA, Kardi K. Phenol-rich compounds sweet gel: a statistically more effective antibiotic than cloxacillin against Pseudomonas aeruginosa. J Pharmacopuncture. 2016;19(3):246-252. doi:10.3831/kpi.2016.19.026 
43. Majtan J, Sojka M, Palenikova H, Bucekova M, Majtan V. Vitamin $\mathrm{C}$ enhances the antibacterial activity of honey against planktonic and biofilm-embedded bacteria. Molecules. 2020;25:992. doi:10. 3390/molecules25040992

44. Hermanns R, Cremers NAJ, Leeming JP. van der Werf ET. Sweet relief: determining the antimicrobial activity of medical grade honey against vaginal isolates of Candida albicans. $J$ Fungi (Basel). 2019;5:85. doi:10.3390/jof5030085

45. Oliveira AMP, Devesa JSP, Hill PB. In vitro efficacy of a honey-based gel against canine clinical isolates of Staphylococcus pseudintermedius and Malassezia pachydermatis. Vet Dermatol. 2018;29:180-e65. doi:10.1111/vde.12533

46. Lotfy M, Badra G, Burham W, Alenzi FQ. Combined use of honey, bee propolis and myrrh in healing a deep, infected wound in a patient with diabetes mellitus. Br J Biomed Sci. 2006;63(4):171-173. doi:10.1080/09674845.2006.11732742

47. Mandel HH, Sutton GA, Abu E, Kelmer G. Intralesional application of medical grade honey improves healing of surgically treated lacerations in horses. Equine Vet J. 2020;52(1):41-45. doi:41-45. doi:10.1111/evj.13111

48. Nair HKR, Tatavilis N, Pospíšilová I, Kučerová J, Cremers NAJ. Medical-grade honey kills antibiotic-resistant bacteria and prevents amputation in diabetics with infected ulcers: a prospective case series. Antibiotics. 2020;9:529. doi:10.3390/antibiotics909052

49. Chatzoulis G, Chatzoulis K, Spyridopoulos P, Pappas P, Ploumis A. Salvage of an infected titanium mesh in a large incisional ventral hernia using medicinal honey and vacuum-assisted closure: a case report and literature review. Hernia. 2012;16:475-479. doi:10.1007/ s10029-010-0767-8

50. Sarhan WA, Azzazy HM. Apitherapeutics and phage-loaded nanofibers as wound dressings with enhanced wound healing and antibacterial activity. Nanomedicine (London, England). 2017;12 (17):2055-2067. doi:10.2217/nnm-2017-0151

51. Oliveira A, Ribeiro HG, Silva AC, et al. Synergistic antimicrobial interaction between honey and phage against Escherichia coli biofilms. Front Microbiol. 2017;8:2407. doi:10.3389/fmicb.2017. 02407

52. Kwakman PH, de Boer L, Ruyter-Spira CP, et al. Medical-grade honey enriched with antimicrobial peptides has enhanced activity against antibiotic-resistant pathogens. Eur J Clin Microbiol Infect Dis. 2011;30(2):251-257. doi:10.1007/s10096-010-1077-x
53. El-Kased RF, Amer RI, Attia D, Elmazar MM. Honey-based hydrogel: in vitro and comparative In vivo evaluation for burn wound healing. Sci Rep. 2017;7(1):9692. doi:10.1038/s41598-017-08771-8

54. Mirzaei B, Etemadian S, Goli H, et al. Construction and analysis of alginate-based honey hydrogel as an ointment to heal of rat burn wound related infections. Int J Burns Trauma. 2018;8(4):88-97.

55. Park JS, An SJ, Jeong SI, Gwon HJ, Lim YM, Nho YC. Chestnut honey impregnated carboxymethyl cellulose hydrogel for diabetic ulcer healing. Polymers. 2017;9:7. doi:10.3390/polym9070248

56. Tavakoli J, Tang Y. Honey/PVA hybrid wound dressings with controlled release of antibiotics: structural, physico-mechanical and in-vitro biomedical studies. Mater Sci Eng C Mater Biol Appl. 2017;77:318-325. doi:10.1016/j.msec.2017.03.272

57. Swift S, Chepulis L, Uy B, Radcliff F. Enhanced antibacterial activity of MGO TM manuka honey complexed with $\alpha$-cyclodextrin (Manuka Honey with CycloPower TM). Func Foods Health Dis. 2014;4 (5):172-181. doi:10.31989/ffhd.v4i5.13

58. Yadav A, Verma S, Keshri GK, Gupta A. Combination of medicinal honey and $904 \mathrm{~nm}$ super pulsed laser-mediated photobiomodulation promotes healing and impedes inflammation, pain in full-thickness burn. J Photochem Photobiol B. 2018;186:152-159. doi:10.1016/j. jphotobiol.2018.07.008

59. Rudzka-Nowak A, Łuczywek P, Gajos MJ, Piechota M. Application of manuka honey and GENADYNE A4 negative pressure wound therapy system in a 55-year-old woman with extensive phlegmonous and necrotic lesions in the abdominal integuments and lumbar region after traumatic rupture of the colon. Med Sci Monit. 2010;16(11): Cs138-142.

60. Mancuso E, Tonda-Turo C, Ceresa C, et al. Potential of manuka honey as a natural polyelectrolyte to develop biomimetic nanostructured meshes with antimicrobial properties. Front Bioeng Biotechnol. 2019;7:344. doi:10.3389/fbioe.2019.00344

61. Minden-Birkenmaier BA, Bowlin GL. Honey-based templates in wound healing and tissue engineering. Bioengineering. 2018;5:46. doi:10.3390/bioengineering5020046

62. Lacopetti I, Perazzi A, Martinello T, Gemignani F, Patruno M. Hyaluronic acid, manuka honey and acemannan gel: wound-specific applications for skin lesions. Res Vet Sci. 2020;129:82-89. doi:10.1016/j.rvsc.2020.01.009

\section{Publish your work in this journal}

Clinical, Cosmetic and Investigational Dermatology is an international, peer-reviewed, open access, online journal that focuses on the latest clinical and experimental research in all aspects of skin disease and cosmetic interventions. This journal is indexed on CAS.
The manuscript management system is completely online and includes a very quick and fair peer-review system, which is all easy to use. Visit http://www.dovepress.com/testimonials.php to read real quotes from published authors. 